\title{
Human Potential in the Context of the COVID-19 Pandemic: Issues of Inequality and Fulfillment Efficiency*
}

\author{
LARISA $V$. SHAULSKa ${ }^{i}$ Olesia V. TOMChuK ${ }^{i i}$
}

\begin{abstract}
The article is devoted to the analysis of the COVID-19 pandemic impact on human potential in the context of overcoming social inequality and ensuring its optimal fulfillment in the face of unexpected and unpredictable threats. The nature of the pandemic impact on economic and social sphere, as well as the most vulnerable areas of the human potential formation and development has been studied. The degree of social inequality influence on the level of social and economic systems of different levels vulnerability, the role of human development indicators in the ability to respond quickly to pandemic threats, to ensure required level of security, and availability of necessary benefits has been defined. It is substantiated that lower levels of human development increase social inequality, deepen problems and crises, neutralize efforts to overcome and prevent the spread of threats, and erroneous decisions and ineffective short-term measures can have a devastating impact in the strategic perspective. Determinants influencing the degree of social and economic systems readiness to respond objectively to the challenges of the pandemic, overcome spatial and social constraints, ensure the continuity of formation and effective fulfillment of human potential are identified. The study revealed necessity to restructure strategic planning of cities as the main centers of human development, which play a critical role in the system for preventing the spread of pandemic threats and are able to maximize economic and social resources to develop effective solutions and consolidate society's efforts in the face of future pandemic risks. The main directions to improve long-term urban planning in order to prevent manifestations of inequality, to ensure quality conditions for building, preservation, development and effective fulfillment of human potential are outlined.
\end{abstract}

Key words: human potential, social inequality, COVID-19, urbanization, urban economy, strategic planning.

Introduction. The year 2020 seemed very difficult for all mankind, and above all, it has exposed problems linked to the development of human potential. Some studies compare current level of deprivation with the crisis of the mid-1980s [1], as the global nature of the crisis caused by global pandemic is negatively reflected in the most important indicators of human development such as income levels, physiological and demographic characteristics, quality and accessibility of education. Declining economic activity, uncontrolled population

\footnotetext{
${ }^{i}$ Larisa V. Shaulska, Dr (Economics), Professor, Professor of the Department of Management of Innovative and Investment activity Taras Shevchenko National University of Kyiv,

ii Olesia V. Tomchuk, PhD (Economics), Associate Professor, Associate Professor of the Department of Management and Behavioral Economics, Vasyl' Stus Donetsk National University

* The publication contains the results of research conducted within the framework of the scientific research work «Integrated development of the territory: personnel, marketing and innovation structures» which is funded by the Grant from the Ministry of Education and Science of Ukraine (No 0117U006342).
}

(C) L. V. Shaulska, O. V. Tomchuk, 2020

https://doi.org/10.21272/mer.2020.90.01 
Larisa V. Shaulska, Olesia V. Tomchuk.

Human Potential in the Context of the COVID-19 Pandemic: Issues of Inequality and Fulfillment Efficiency

failure and rising child mortality, limited opportunities for learning and development (particularly in preschool and school education) and other seemingly implicit consequences significantly exacerbate existing problems of economic and social inequality, affect the efficiency of human potential fulfillment in current conditions and strategic perspective. As evidenced by statistics on the rate of disease spread and death cases the most vulnerable were those territories and countries where the level of human development in the pre-crisis period was low, while in more developed societies pandemic has accelerated the process of balancing economic feasibility and social necessity in making management decisions to overcome and prevent its costs.

Pandemic has had significant consequences in the field of human development, primarily in cities and other urban areas that have historically been centers of gravity for human resources, an environment for the effective building, preservation and application of human capabilities, creative class shaping and sustainable economic dynamics provided by its rational use. At the same time, cities became epicenters of the pandemic given the higher levels of the population, advanced networks of global and national relationships, more obvious manifestations of social inequality etc. Despite the fact that cities have accumulated resources and tools to overcome and prevent effectively pandemic consequences the health crisis threatens to turn into a crisis of urban accessibility, capital distribution and utilization, security, employment and unemployment, development of social and spatial infrastructure, which will only exacerbate the existing disparities in human development. The above necessitates the study of the key human development vulnerabilities identified by the pandemic in order to develop a coherent, multidimensional and systematic approach to the implementation of territorial and urban development management policies in the context of overcoming current and preventing possible threats to human potential development, protection and fulfillment.

Analysis of the recent publications. The scientific research of G. Brown, D. Dobrov, A. Kolot, E. Libanova [2], Ye. Sulima [3] etc. are devoted to the study of social inequality and disproportions in the development of human potential, where the nature of the emergence and spread of inequality, determinants and trends in human development crisis phenomena are deepened and effective overcoming mechanisms are exposed; the limiting impact of inequality on the fulfillment efficiency of human potential was substituted. The problems of establishment and development of human potential in social and economic systems of different levels are given considerable attention in the study of O. Grishnova, O. Krushelnytska, P. Hudzya, L. Melnyk [4], A. Tkachenko, V. Sepeta [5], L. Ivanova [6]. The challenges of human development caused by the effects of the COVID-19 pandemic are being actively studied by many authors with the support of international organizations (including the UN, WHO, World Bank) in order to identify the most proper trends, record policy and management decisions, develop agreed programs of coordinated efforts to meet and overcome such kind of threats. Without diminishing the soundness and significance of previous scientific results we consider it expedient to conduct a comprehensive analysis of human development trends in the COVID-19 pandemic, identify the most significant factors and key issues of its effective fulfillment, develop recommendations to overcome negative trends and prevent future human development crises. To achieve this goal, the following tasks are defined:

- to characterize human development tendencies in the conditions of pandemic and social inequality reinforcement; 
Л. В. Шаульська, О. В. Томчук.

Людський потенціал в умовах пандемії COVID19: питання нерівності та ефективності використання

- to identify factors and key issues of development, preservation and fulfillment of human potential of cities in the context of overcoming and preventing the consequences of COVID-19;

- to substantiate necessity of multidimensional and systematic approach to the implementation of territorial development management policy application in order to eliminate and prevent unforeseen threats to the human potential effective fulfillment.

Research results. The scale of the global impact of the COVID-19 epidemic at the beginning of its emergence was characterized by unexpectedness and unpredictability of spreading, which required a concentration of efforts for not only national but everyone survival. All spheres of human being are threatened due to the application of sanitary and epidemiological measures, restriction of spatial movement and employment, establishment of distance learning and education. The corresponding slowdown in economic growth, which has affected most countries in the world, including the EU and Ukraine, is understandable. The ratio of GDP losses in different Eurozone countries in the first quarter of 2020 compared to the previous three quarters of 2019 averaged by $3.8 \%$ decline, including $2.6 \%$ in Austria, $5.2 \%$ in Spain, $5.3 \%$ in France, $5.6 \%$ in Italy [7].

In general, the average annual decline in real GDP in developed economies was $3.9 \%$, in developing economies $-6.0 \%$, the world average $-5.2 \%$ (Fig. 1) [8].

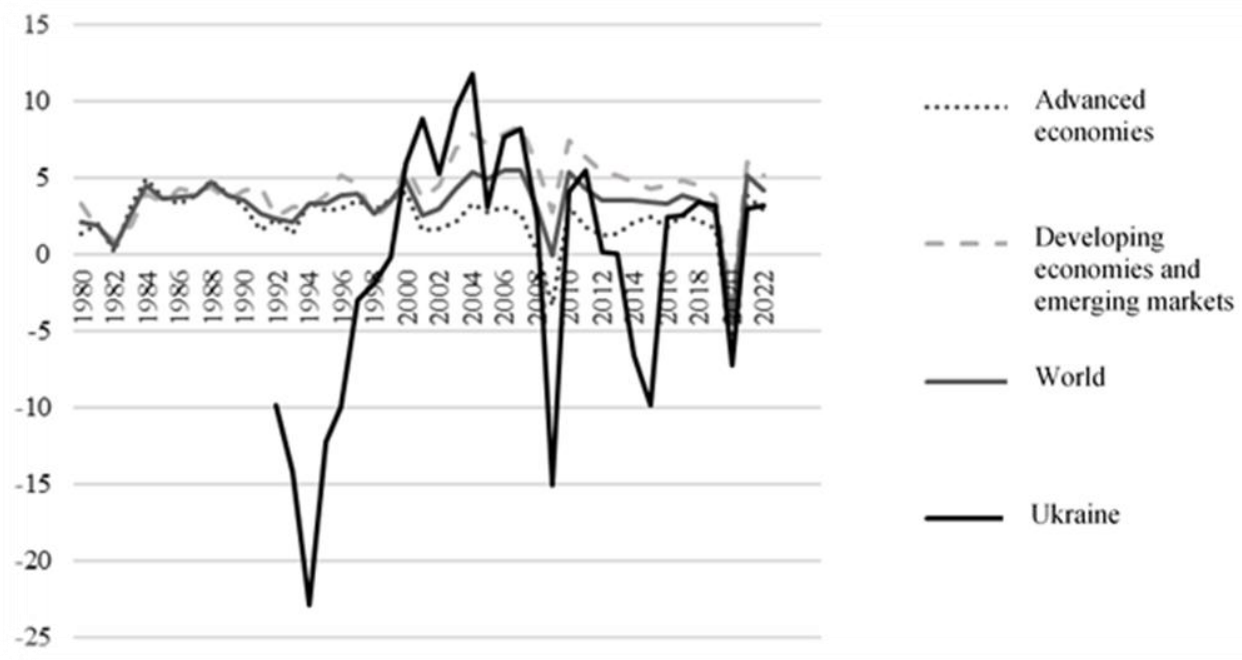

Figure 1. Dynamics of real GDP average annual growth in the regions of the world and Ukraine

In Ukraine, the most difficult was the second quarter of 2020 (1.5\% decline in GDP) during the tightest sanitary and epidemiological restrictions, and the subsequent easing of measures allowed to keep the average annual decline in GDP at $3.0 \%$.

The mitigation of negative economic effects impact on Ukraine's economy is primarily had happened due to the preservation of positive wages and consumer demand dynamics, at the same time, some consequences were devastating, in particular in the international economic and human development domain (employment and unemployment, health care), education and 
Larisa V. Shaulska, Olesia V. Tomchuk.

Human Potential in the Context of the COVID-19 Pandemic: Issues of Inequality and Fulfillment Efficiency

training, availability of social infrastructure etc.). Thus, the level of official unemployment in Ukraine, despite a certain revival of economic activity in the middle of the year increased by an average of $1.0 \%$ (Fig. 2) [9].

In general, the COVID-19 pandemic has revealed the depth of the systemic human development and social inequality crisis over time, and at the same time its importance in the context of countries and regions of the world readiness to respond properly to unpredictable and large-scale threats.

Economic theorist U. Hack insists that the main causes of pandemic are poverty, lack of health care and nature protection at the global level [10]. Social inequality, limited access to quality products and services, low welfare are objective causes of such kind of threats, and deficiency of comprehensive political and managerial solutions to overcome this vulnerability significantly increases the likelihood of further devastating impact of such cases on the global social and economic system.

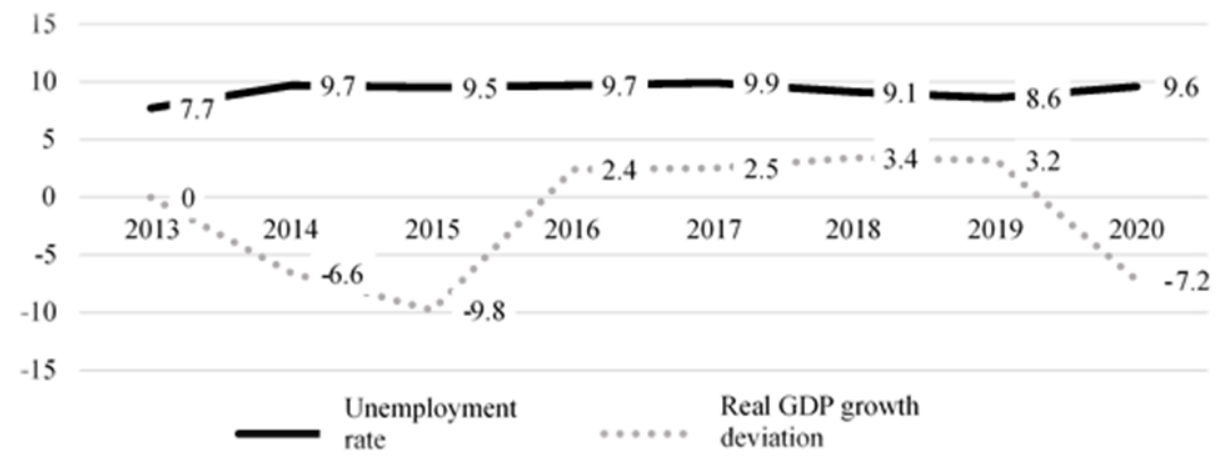

Figure 2. Dynamics of the unemployment rate and real GDP growth of Ukraine in 2013$2020, \%$

Inequality can take many forms: class, political, economic, educational, health, environmental, cultural, informational etc. [11] and lead to the preservation of poverty, rising social tensions and mistrust in society, macroeconomic instability, limiting economic and social development. A significant gap in income levels and the availability of vital goods hinders building and development of human potential of the required quality and quantity as the main productive force, further limiting the possibilities of its effective fulfillment to ensure national and local competitiveness. First of all, inequality affects the physical parameters of human potential (population size and dynamics of reproduction, level of health, average life expectancy, availability of quality education) and the conditions of its building (income level, employment and unemployment rate, technology development, social environment), which does not allow to create a favorable basis for free personal development and self-realization of the individual.

The social and economic crisis caused by pandemic has shown that in countries with high levels of social inequality and low human development indices there is a generally higher number of deaths, faster and more uncontrolled spread and fast overload of the health care system. In countries with high inequalities in class, age, gender, ethnicity or social status the consequences may exacerbate these differences at least in the short term. Vulnerable groups 
Л. В. Шаульська, О. В. Томчук.

Людський потенціал в умовах пандемії COVID19: питання нерівності та ефективності використання

are disproportionately affected: the elderly, women, young professionals and workers, people living in shelters and those with initial health problems.

Despite the first-place negative impact on developed economies they were able to respond quickly to the challenges of pandemic through a strong health care system, support from a stable monetary system, flexible fiscal policies, consolidation of societal efforts and governance systems. For less developed countries the situation has only exacerbated all previous problems.

It should be noted that pandemic has significantly increased the risks of vulnerability for those parts of population who, even before it began, experienced the constraints caused by inequality. Social distancing for low-income categories has proved critical in terms of employment opportunities, while higher-income categories have retained the opportunity to work remotely [1]. Limited access to essential medical services, quality education, decent and safe living conditions, comfortable public space further undermines the ability to respond effectively to COVID-19 threats.

Studies show that the factors that have ensured a higher level of preparedness for pandemic challenges include the level of human development (HDI, inequality in HDI), the reliability of the health care system (the number of medical workers and hospital beds per 10,000 population, current health expenditure), the ubiquity of electronic communications networks (mobile and broadband subscriptions) and key vulnerabilities include poverty level, indicators of imminent economic instability (population without any social protection and labour programs, remittances and inflows \% of GDP) (Table 1) [12].

Table 1

Preparedness and vulnerability to the challenges posed by the COVID-19 pandemic determinants

\begin{tabular}{|c|c|c|c|c|c|}
\hline \multirow[t]{2}{*}{ Determinants } & \multicolumn{4}{|c|}{ Human Development Groups } & \multirow[b]{2}{*}{ Ukraine } \\
\hline & $\begin{array}{l}\text { Very } \\
\text { high }\end{array}$ & High & Middle & Low & \\
\hline $\begin{array}{l}\text { Human development } \\
\quad \text { - HDI } \\
\text { - inequality in HDI, \% }\end{array}$ & $\begin{array}{c}0,892 \\
10,8 \\
\end{array}$ & $\begin{array}{c}0,750 \\
17,9 \\
\end{array}$ & $\begin{array}{c}0,634 \\
20,0 \\
\end{array}$ & $\begin{array}{c}0,507 \\
31,1 \\
\end{array}$ & $\begin{array}{c}0,750 \\
6,5 \\
\end{array}$ \\
\hline $\begin{array}{l}\text { Reliability of health care system } \\
\text { - the number of medical workers per } 10,000 \\
\quad \text { population } \\
\text { - hospital beds per } 10,000 \text { population } \\
\text { - - current health expenditure, } \% \text { to GDP }\end{array}$ & $\begin{array}{c}70,9 \\
55 \\
12,0\end{array}$ & $\begin{array}{c}23,2 \\
32 \\
5,7\end{array}$ & $\begin{array}{c}12,1 \\
9 \\
3,9\end{array}$ & $\begin{array}{c}5,1 \\
6 \\
4,5\end{array}$ & $\begin{array}{c}50,5 \\
88 \\
6,7 \\
\end{array}$ \\
\hline $\begin{array}{l}\text { Ubiquity of electronic communications networks } \\
\text { - mobile phone subscription, per } 100 \text { people } \\
\text { - fixed broadband subscriptions, per } 100 \\
\text { people }\end{array}$ & $\begin{array}{c}127,8 \\
30,5\end{array}$ & $\begin{array}{c}113,6 \\
18,8\end{array}$ & $\begin{array}{c}91,9 \\
2,4\end{array}$ & $\begin{array}{c}67,5 \\
0,4\end{array}$ & $\begin{array}{c}122,6 \\
12,8\end{array}$ \\
\hline Poverty level & - & 10,4 & 23,0 & 44,0 & 1,3 \\
\hline $\begin{array}{l}\text { Imminent economic instability indicators } \\
\text { - population without any social protection and } \\
\text { labour programs \% } \\
\text { - remittances, inflows, \% of GDP }\end{array}$ & $\begin{array}{c}31,3 \\
0,3\end{array}$ & $\begin{array}{c}38,8 \\
1,0\end{array}$ & $\begin{array}{c}31,9 \\
4,1\end{array}$ & $\begin{array}{c}86,1 \\
4,6\end{array}$ & $\begin{array}{l}29,7 \\
11,0\end{array}$ \\
\hline
\end{tabular}

As we can see, Ukraine is one of the countries with a high level of human development and despite the threats it has made slow but steady progress. However, in the future the basic parameters of human development should be expanded to the level of high-quality services in 
Larisa V. Shaulska, Olesia V. Tomchuk.

Human Potential in the Context of the COVID-19 Pandemic: Issues of Inequality and Fulfillment Efficiency

the medical and educational spheres, availability of breakthrough technologies, ensuring resilience to new, unpredictable threats.

The trends of the pandemic's influence on the formation and fulfillment of human potential are more clearly reflected in the processes of urbanization. Historically cities have been centers of attraction for human potential carriers, offering higher living standards and a quality environment for comprehensive development and growth. Intensification of urban development leads to a simultaneous growth in economic dynamics but increasing social pressure, which in a pandemic affects the ability of cities to respond to its spread, utilize resources efficiently and develop overcoming and prevention policies.

On average in $90 \%$ of cases cities are the epicenters of the virus [13] due to population density, high level of local and global interconnectedness. However, they are centers of human, financial, innovative and creative resources, which effective fulfillment allows rapid implementation of restrictive measures and development of alternatives to overcome the effects of pandemic.

Studies of the COVID-19 impact on urban development conducted in 2020 have identified key factors and mechanisms that contribute to or limit the spread of the virus in cities [14]. These include environmental factors (air and water quality, the use of "green" energy), social and economic (level of community cohesion, trust and social consciousness, economic sustainability), management and political (quality of public administration, level of smart-city solutions implementation), infrastructure and urban design (issues of mobility and accessibility of urban services, rational spatial planning) [15].

Environmental reasons determine the overall level of health and physiological parameters of the population, are reflected in life expectancy, resistance to disease; social characterize the degree of inequality and tension among the inhabitants of the community which determines the level of trust, ability to overcome class and social separations in order to focus efforts on overcoming the threat; economic characterize the availability of financial resources to ensure anti-epidemic measures, support for vulnerable populations and areas of the city's economy; the effectiveness of local management in general characterizes the quality of current and longterm management decisions on urban development and prevention of unexpected threats; availability of required social and transport infrastructure, level of mobility help to avoid unpredictable crowds of people, meet the necessity of various goods without requirement to make long rides, affects the quality of distance work and learning etc.

In general, all these components simultaneously serve as basic conditions for the development of the environment for reproduction and shaping human potential of cities, which indicates the necessity to expand urban planning measures considering anti-epidemic requirements.

For the most part the main restrictive measures to prevent the spread of epidemic are lockdowns, closure of educational institutions, restrictions on movement (Fig. 3) [16]. In addition, these measures were further reinforced by the requirements for the use of personal protective equipment, social distancing etc.

The application of restrictive measures had a corresponding effect, but in the short term, as it was aimed at slowing down the spread of the virus in order to prevent overloading the state medical system [17]. However, without appropriate financial, economic and fiscal measures designed to support particularly vulnerable populations and domains of the economy such decisions will have a negative impact in the long run. 
Л. В. Наульська, О. В. Томчук.

Людський потенціал в умовах пандемії COVID19: питання нерівності та ефективності використання

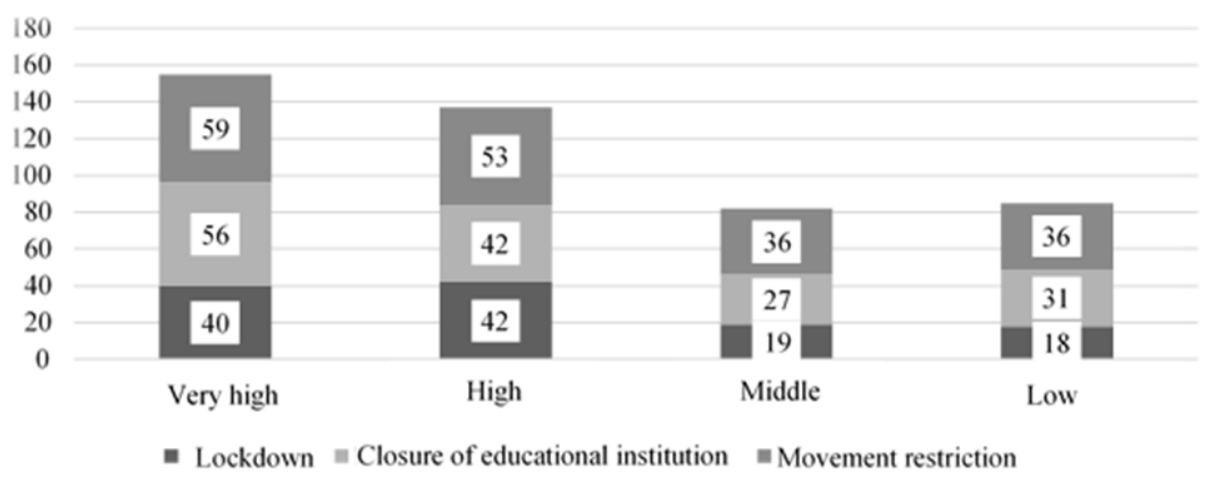

Figure 3. The main restrictive measures by groups of countries in terms of human development, number of countries

Households and individuals at risk of social inequality, as well as those at risk of poverty due to reduced physiological parameters (loss of health, reduced life expectancy), access to quality education (lack of tools or skills for distance learning) ), loss of permanent employment (reduction of staff, lack of conditions or inability to remote employment, guarantees of social protection), most acutely affected by restrictions and in some cases have suffered significant losses of individual human potential [18]. In addition, the field of employment, education, services, tourism and others have undergone significant transformations, which requires a review of existing approaches and regulatory mechanisms, finding areas for restructuring and diversification of the local economy.

In view of the above, urban and territorial development strategies should be reviewed in the context of preparedness for unforeseen future threats, should consider the specifics of cities, its benefits and opportunities to provide quality environment for human potential shaping and development, work systematically to protection all segments of the population against social inequalities. In addition, considerable attention should be paid to the diversification of the urban economy, which will consider the threat of sudden spatial constraints and social distancing, the possibility to apply modern technologies and its availability, level of protection of remote employment, quality of educational services.

It should also be noted that the development of strategic economic programs of cities slowed down due to reduced production, mass layoffs and remote employment, loss of consumers, rising costs for the implementation of sanitary measures at work, providing personnel with personal protective equipment, retraining, according to the requirements of measures to combat the pandemic, reduce funding for social programs. Individual enterprises and SME cluster which could not reorient quickly or did not have enough financial strength were particularly affected, so additional efforts in this direction are required.

Particular attention have to be paid to the organization of accessible and quality education, in order to provide effective organization of the educational process and the formation correct learning process of distance and blended learning, to ensure continuity of skills and competencies in the context of individualization of educational trajectories.

Safety measures implemented in the process of combating the coronavirus force people to abandon common stereotypes of behavior (of common way of physiological recovery 
Larisa V. Shaulska, Olesia V. Tomchuk.

Human Potential in the Context of the COVID-19 Pandemic: Issues of Inequality and Fulfillment Efficiency

abandonment, travel reduction, cultural development restrictions). This requires a conscious change in daily behavior and focus on developing alternatives that support the formation of a healthy lifestyle, develop skills of self-improvement and creative thinking development.

Some Urban Development Strategies of Ukraine provided development scenarios due to the impact of the changing external environment: pessimistic, real, optimistic, but no program considers the scenario associated with the threat of epidemics. Therefore, the key areas of transformation strategic urban development planning in order to ensure the effective building and fulfillment of human potential should include:

1. Elimination of any social inequality manifestations, expansion of social guarantees for socially vulnerable groups, strengthening of human rights. First of all, it should be implemented on the basis of inequality and causes deep analysis and monitoring, next is identification of bottlenecks and problems of social and economic nature, development directions to expand access to health services, increasing welfare, upgrading urban and housing infrastructure, spatial planning and advance of the transport network, ensuring equal opportunities to receive required social services at a high level.

2. Strengthening the role of local actors, reinforcing partnership between territorial management system and community representatives, developing trust, increasing the social potential of cities. Strategic issues of public administration should consider the sources of emergent involving of additional financial resources (operation of special funds on the basis of transparency and targeting), achieving a flexible tax system (temporary reduction of tax pressure without significant losses to the budget and economic efficiency), improving communications, fairness provision of public services.

3. Ensuring formation of sustainable, inclusive and the most equitable type of economic planning, development of financial support programs for SME cluster to restart business, social insurance programs for employees of the informal sector. Sustainable development strategies should provide opportunities for economic diversification of mono-specialized cities, focus on sectors with the potential for environmental transformation (green energy, environmentally sustainable urban planning and construction, food and water supply), be based on the principle of "man above all" and maximize human development.

Conclusions. The crisis caused by the global pandemic can be described as global and unpredictable, which negatively affects the most important indicators of human development (income constraints, reduced physiological and demographic characteristics, violations of justice in access to quality social infrastructure etc.). At the same time, most vulnerable are those areas and regions that are characterized by a low level of human development, where there is a faster and uncontrolled spread of the virus, number of fatal cases, rising social pressure and inequality. On the one hand, social inequality is the primary cause of increased risk of such phenomena in the future, on the other, it offsets most efforts to overcome negative effects of social stratification and increase human development. As a result, more developed societies consolidate efforts to strike a well-adjusted balance between economic feasibility and social necessity in making management decisions to overcome and prevent the consequences of the pandemic, and in less developed negative phenomena only intensify threats, preventing any positive progress.

The pandemic significantly increases the vulnerability of weak groups, as social and spatial distancing for low-income categories is critical in terms of employment opportunities, access to essential health services, quality education, decent and safe living conditions, comfortable public space and strengthening social tensions, declining confidence and desire for cooperation needed to develop effective solutions to overcome the effects of the pandemic. 
Л. В. Шаульська, О. В. Томчук.

Людський потенціал в умовах пандемії COVID19: питання нерівності та ефективності використання

Ukraine is included in the list of countries with a high level of human development, however, in order to increase the resilience of the national social and economic system to threats of this type the basic parameters for effective development and fulfillment of human potential should be expanded to high quality.

Analysis of the impact of pandemic on the human potential of cities has identified key factors and mechanisms that contribute to or limit the spread of the virus (environmental, social and economic, managerial and political, infrastructure and urban design), which become determinants of sanitary and epidemiological constraints. Urban and territorial development strategies need to be substantially revised and refined in the context of preparedness for unforeseen future threats, and the priority is to implement measures that will ensure the continuous and high-quality building of human potential of cities, contribute to its preservation, development and efficient fulfillment. The main areas for improving long-term urban planning include the elimination of all social inequality manifestations (social guarantees for vulnerable groups, strengthening human rights, expanding access to health services, increasing welfare, upgrading urban and housing infrastructure, spatial planning and advancing of transport network, ensuring equal opportunities); strengthening the role of local actors (reinforcing partnership between territorial management system and community representatives, developing trust, increasing social potential of cities); ensuring compliance with the principles of sustainability, inclusiveness and equity in the implementation of economic planning (opportunities for economic diversification, concentration on fields with the potential for environmental transformation, human-centered paradigm).

\section{References}

1. COVID-19 and human development: Assessing the Crisis, Envisioning the Recovery (2020). United Nations Development Programme. New York.

2. Libanova, E. M. (2015). Liudskyi rozvytok v Ukraini. Modernizatsiia sotsialnoi polityky: rehionalnyi aspect [Human development in Ukraine. Modernization of social policy: regional aspect]. Kyiv: In-t demohrafii ta sotsialnykh doslidzhen im. M. V. Ptukhy NAN Ukrainy [in Ukrainian].

3. Sulima, Ye. M. (2004). Dzherela globalnoyi socialnoyi nerivnosti ta shlyaxy podolannya polyaryzaciyi globalnogo suspilstva [Sources of global social inequality and ways to overcome the polarizations of global society]. Retrieved from: http://eprints.zu.edu.ua/1520/1/04sempgs.pdf [in Ukrainian].

4. Melnyk, L. G. (2019). Kreatyvnyj lyudskyj kapital yak faktor formuvannya vyrobnychogo potencialu [Creative human capital as a factor in the formation of production potential]. III Mizhnarodna naukovo-praktychna konferenciya «Ekonomichnyj rozvytok derzhavy ta yiyi socialna stabilnist» - III International scientific-practical conference "Economic development of states and its social stability». Poltava: FOP Pusan A. F., 110-112. [in Ukrainian].

5. Tkachenko, A., Sepeta, V. (2017). Pidvyshhennya konkurentospromozhnosti promyslovyx pidpryyemstv za raxunok efektyvnosti vykorystannya trudovogo potencialu [Improving the competitiveness of industrial enterprises through the efficient use of labor potential]. Visnyk Khmelnytskoho nacionalnogo universytetu - Bulletin of Khmelnytsky National University, 3(1), 61-65 [in Ukrainian].

6. Ivanova, L. I. (2018). Lyudskyj potencial: demografichni chynnyky jogo formuvannya v suchasnyx umovax [Human potential: demographic factors of its formation in modern conditions]. Visnyk socialno-ekonomichnyx doslidzhen Odeskogo nacionalnogo ekonomichnogo universytetu - Bulletin of socio-economic research of Odessa National Economic University, 3(67), 131-139 [in Ukrainian].

7. Ukrayina: vplyv COVID-19 na ekonomiku i suspilstvo (bachennya postpandemichnogo rozvytku u 2020-2024 rr. ochyma ekspertiv ta molodi) [Ukraine: the impact of KOVID-19 on the economy and society (vision of post-pandemic development in 2020-2024 through the eyes of experts and youth)] (2020). Departament strategichnogo planuvannya ta makroekonomichnogo prognozuvannya 
Larisa V. Shaulska, Olesia V. Tomchuk. Human Potential in the Context of the COVID-19 Pandemic: Issues of Inequality and Fulfillment Efficiency

Ministerstva rozvytku ekonomiky, torgivli ta silskogo gospodarstva Ukrayiny, 52, 50 p. [in Ukrainian].

8. Real GDP growth 2020. International Monetary Fund. Retrieved from: https://www.imf.org/external/datamapper/.

9. Bezrobittya naselennya (za metodologiyeyu MOP) za stattyu, typom miscevosti ta vikovymy grupamy [Unemployment of the population (according to the ILO methodology) by sex, type of area and age groups]. Derzhavnyj komitet statystyky Ukrayiny. Retrieved from: http://www.ukrstat.gov.ua/operativ/operativ2017/rp/eans/eans_u/arch_bnsmv_u.htm [in Ukrainian].

10. What coronavirus teaches us about the kind of world we have to build (2020). Hack, Umair. Retrieved from: https://www.medium.com/@umairh/what-coronavirus-teaches-us-about-the-kind-ofworld-we-have-to-build-bc5822d5779e.

11. Libanova, E. M. (2012). Nerivnist v Ukrayini: masshtaby ta mozhlyvosti vplyvu [Inequality in Ukraine: scale and opportunities for influence]. Kyiv: Instytut demografiyi ta socialnyx doslidzhen imeni M.V. Ptuxy NAN Ukrayiny, 404 p. [in Ukrainian].

12. COVID-19 and human development: Exploring global preparedness and vulnerability (2020). Human Development Report Office. UNDP, 5 p.

13. Semeh, Wahba \& et al. (2020). Cities are on the front lines of COVID-19. World bank blogs. Retrieved from: https://blogs.worldbank.org/sustainablecities/cities-are-front-lines-covid-19.

14. Opinion: COVID-19 demonstrates urgent need for cities to prepare for pandemics (2020). United Nations Human Settlements Programme (UN-Habitat). Retrieved from: https://unhabitat.org/opinion-covid-19-demonstrates-urgent-need-for-cities-to-prepare-for-pandemics

15. Ayyoob Sharifi, Amir Reza Khavarian-Garmsir (2020). The COVID-19 pandemic: Impacts on cities and major lessons for urban planning, design, and management. Science of The Total Environment, 749. DOI: 10.1016/j.scitotenv.2020.142391.

16. COVID-19 government measures dataset. Acaps. Retrieved from: https://www.acaps.org/covid-19government-measures-dataset.

17. OECD Policy Responses to Coronavirus (COVID-19) (2020). Organization for Economic Cooperation (OECD). Retrieved from: http://www.oecd.org/coronavirus/policy-responses/citiespolicy-responses-fd1053ff.

18. Jillian Du, Robert King and Radha Chanchani (2020). Tackling Inequality in Cities is Essential for Fighting COVID-19. Retrieved from: https://www.wri.org/blog/2020/04/coronavirus-inequalitycities.

Manuscript received 20 September 2020

Человеческий потенциал в условиях COVID-19: вопросы неравенства и эффективности использования

\section{ШАУЛЬСКАЯ ЛАРИСА ВЛАДИМИРОВНА ТОМЧУК ОЛЕСЯ ВАЛЕРЬЕВНА* ,}

* доктор экономических наук, профессор

профессор кафедры менеджмента, инновационной и инвестиционной деятельности

Киевского национального университета имени Тараса Шевченка,

ул. Владимирская, 60, 01033, г. Киев, Украина

тел.: 00-380-44-2393333, e-mail: shaulska@knu.ua

*** кандидат экономических наук, дочент, дочент кафедры менеджмента и поведенческой экономки Донеикого наиионального университета имени Васыля Стуса,

ул. 600-летия, 21, 21021, г. Винница, Украина,

тел:00-380-432-508948,e-mail:o.tomchuk@donnu.edu.ua 
Л. В. Шаульська, О. В. Томчук.

Людський потенціал в умовах пандемії COVID19: питання нерівності та ефективності використання

Статья посвящена анализу влияния пандемии COVID-19 на человеческий потенциал в контексте новых аспектов социального неравенства и обеспечения рационального использования человеческого потенциала в условиях неожиданных угроз и трудно прогнозируемых факторов влияния. Исследован характер влияния пандемии на экономическую и социальную сферу, а также наиболее уязвимые сферы формирования и развития человеческого потенциала. Определена степень влияния социального неравенства на уязвимость социально-экономических систем разных уровней, роль показателей человеческого развития в способности быстро реагировать на пандемические угрозы, обеспечивать необходимый уровень защищенности, доступности необходимых благ. Обосновано, что более низкие уровни человеческого развития усиливают социальное неравенство, углубляют проблемы и кризисы, нивелируют усилия по преодолению и предупреждению распространения угроз, а ошибочные решения и неэффективные краткосрочные меры могут оказать разрушительное влияние в стратегической перспективе. Систематизированы факторы, влияющие на степень готовности социально-экономических систем объективно реагировать на вызовы пандемии, преодолевать пространственные и социальные ограничения, обеспечивать непрерывность формирования и эффективного использования человеческого потенциала. Охарактеризованы перспективы реструктуризации процессов стратегического планирования городов, как основных центров человеческого развития, которые играют важнейшую роль в системе предотвращении распространения пандемических угроз, способны оптимально использовать экономические и социальные ресурсы для разработки эффективных решений и консолидации усилий общества в условиях будущих пандемических или подобных рисков. Обозначены основные направления усовершенствования долгосрочного городского планирования с целью предотвращения проявлений неравенства, обеспечения качественных условий для формирования, сохранения, развития и эффективного использования человеческого потенциала.

Ключевые слова: человеческий потенциал, социальное неравенство, COVID-19, урбанизация, экономика городов, стратегическое планирование.

$$
\begin{gathered}
\text { Mechanism of Economic Regulation, 2020, No 4, 6-18 } \\
\text { ISSN 1726-8699 (print) }
\end{gathered}
$$

\title{
Людський потенціал в умовах пандемії COVID19: питання нерівності та ефективності використання
}

\author{
ШАУЛЬСЬКА ЛАРИСА ВОЛОДИМИРІВНА*, \\ ТОМчУК ОЛЕСЯ ВАЛЕРІЇвНА**, \\ * доктор економічних наук, професор, \\ професор кафедри менеджменту інноваційної та інвестииійної діяльності \\ Київського начіонального університету імені Тараса Шевченка, \\ вул. Володимирська, 60, 01033, м. Київ, Украӥна \\ тел.: 00-380-44-2393333, e-mail: shaulska@knu.ua
}

** кандидат економічних наук, доцент, доцент кафедри менеджменту та поведінкової економіки Донецького національного університету імені Василя Стуса, вул. 600-річчя, 21, 21021, м. Вінниия, Украӥна,

тел:00-380-432-508948,e-mail:o.tomchuk@donnu.edu.ua

Статтю присвячено аналізу впливу пандемії COVID-19 на людський потенціал в контексті подолання соціальної нерівності і забезпечення його оптимального використання в умовах несподіваних і непрогнозованих загроз. Досліджено характер впливу пандемії на економічну і соціальну сферу, а також найбільш вразливі сфери формування і розвитку людського потенціалу. Визначено ступінь впливу соціальної нерівності на вразливість соціально-економічних систем 
Larisa V. Shaulska, Olesia V. Tomchuk.

Human Potential in the Context of the COVID-19 Pandemic: Issues of Inequality and Fulfillment Efficiency

різних рівнів, роль показників людського розвитку в здатності швидко реагувати на пандемічні загрози, забезпечувати необхідний рівень захищеності, доступності необхідних благ. Обгрунтовано, що в більш низькі рівні людського розвитку в умовах пандемії посилюють соціальну нерівність, поглиблюють проблеми і кризи, нівелюють зусилля 3 подолання та запобігання поширенню загроз, а помилкові рішення і неефективні короткострокові заходи можуть спричинити руйнівного впливу в стратегічній перспективі. Виявлено фактори, що впливають на ступінь готовності соціально-економічних систем об'єктивно реагувати на виклики пандемії, долати просторові і соціальні обмеження, забезпечувати безперервність формування і ефективного використання людського потенціалу. Дослідження виявило необхідність реструктуризації стратегічного планування міст, як основних центрів забезпечення людського розвитку, які відіграють найважливішу роль системі запобігання поширенню пандемічного загроз, здатні оптимально використовувати економічні та соціальні ресурси для розробки ефективних рішень та консолідації зусиль суспільства в умовах майбутніх пандемічний ризиків. Окреслено основні напрямки удосконалення довгострокового міського планування 3 метою запобігання проявам нерівності, забезпечення якісних умов для формування, збереження, розвитку і ефективного використання людського потенціалу.

Ключові слова: людський потенціал, соціальна нерівність, COVID-19, урбанізація, економіка міст, стратегічне планування.

JEL Codes: H10, H51, I00, J01

Tables: 1; Figures: 3, References: 18

Language of the article: English

Лimepamypa

1. COVID-19 and human development: Assessing the Crisis, Envisioning the Recovery / United Nations Development Programme, New York. 2020. - 35 p.

2. Лібанова, E. М. Людський розвиток в Україні. Модернізація соціальної політики: регіональний аспект (колективна монографія) / за заг. ред. Е. М. Лібанової. - Ін-т демографії та соціальних досліджень ім. М. В. Птухи НАН України. - К., 2015. - 356 с.

3. Суліма, С. М. Джерела глобальної соціальної нерівності та шляхи подолання поляризації глобального суспільства [Електронний ресурс] / Є.М. Суліма. - Режим доступу : http://eprints.zu.edu.ua/1520/1/04sempgs.pdf.

4. Мельник, Л. Г. Креативний людський капітал як фактор формування виробничого потенціалу / Л. Г. Мельник // Матеріали III Міжнародної науково-практичної конференції «Економічний розвиток держави та ii соціальна стабільність» (15 травня 2019 р.). - Полтава : ФОП Пусан А. Ф., 2019. - С.110-112.

5. Ткаченко, А. Підвищення конкурентоспроможності промислових підприємств за рахунок ефективності використання трудового потенціалу / А. Ткаченко, В. Сепета // Вісник Хмельницького національного університету. 2017. - № 3(1). - С. 61-65.

6. Іванова, Л. І. Людський потенціал : демографічні чинники його формування в сучасних умовах / Л. І. Іванова // Вісник соціально-економічних досліджень Одеського національного економічного університету. 2018. - № 3(67). - С. 131-139.

7. Україна: вплив COVID-19 на економіку і суспільство (бачення постпандемічного розвитку у 2020-2024 рр. очима експертів та молоді) / Консенсус-прогноз. Департамент стратегічного планування та макроекономічного прогнозування Міністерства розвитку економіки, торгівлі та сільського господарства України. 2020 - № $52 .-50$ с.

8. Real GDP growth 2020 [Електронний ресурс] / International Monetary Fund. - Режим доступу : https://www.imf.org/external/datamapper/.

9. Безробіття населення (за методологією МОП) за статтю, типом місцевості та віковими групами. Статистична інформація [Електронний ресурс] / Державний комітет статистики України. - - Режим доступу http://www.ukrstat.gov.ua/operativ/operativ2017/rp/eans/eans_u/arch_bnsmv_u.htm. 
Л. В. Наульська, О. В. Томчук.

Людський потенціал в умовах пандемії COVID19: питання нерівності та ефективності використання

10. Hack Umair. What coronavirus teaches us about the kind of world we have to build [Електронний pecypc] / Hack Umair. - Режим доступу: https://www.medium.com/@umairh/what-coronavirusteaches-us-about-the-kind-of-world-we-have-to-build-bc5822d5779e.

11. Лібанова, E. M. Нерівність в Україні: масштаби та можливості впливу / За ред. Е. М. Лібанової. - Київ : Інститут демографії та соціальних досліджень імені М.В. Птухи НАН України, 2012. - 404 с.

12. COVID-19 and human development: Exploring global preparedness and vulnerability / Human Development Report Office, UNDP, 2020. - 5 p.

13. Semeh Wahba and others, «Cities are on the front lines of COVID-19» [Електронний ресурс] / Semeh Wahba, 2020. - Режим доступу : https://blogs.worldbank.org/sustainablecities/cities-arefront-lines-covid-19.

14. United Nations Human Settlements Programme (UN-Habitat) [Електронний ресурс] / «Opinion: COVID-19 demonstrates urgent need for cities to prepare for pandemics», 2020. - Режим доступу : https://unhabitat.org/opinion-covid-19-demonstrates-urgent-need-for-cities-to-prepare-for-pandemics

15. Ayyoob, Sharifi. The COVID-19 pandemic: Impacts on cities and major lessons for urban planning, design, and management / Ayyoob Sharifi, Amir Reza Khavarian-Garmsir // Science of The Total Environment. 2020. - № 749. DOI: 10.1016/j.scitotenv.2020.142391.

16. COVID-19 government measures dataset [Електронний ресурс] / Acaps. - Режим доступу : https://www.acaps.org/covid-19-government-measures-dataset.

17. OECD Policy Responses to Coronavirus (COVID-19) [Електронний pecypc] / Organization for Economic Cooperation (OECD). 2020. - Режим доступу : http://www.oecd.org/coronavirus/policyresponses/cities-policy-responses-fd1053ff.

18. Jillian, Du. «Tackling Inequality in Cities is Essential for Fighting COVID-19» [Електронний pecypc] / Du Jillian, King Robert and Chanchani Radha. 2020. - Режим доступу: https://www.wri.org/blog/2020/04/coronavirus-inequality-cities. 